\title{
Bispectral index assessment in calves subjected to the continuous infusion of propofol combined with fentanyl administration
}

\author{
Mauricio Deschk $^{1 *}$ Thomas Alexander Trein ${ }^{2}$ Juliana Tessália Wagatsuma ${ }^{2}$ \\ Guilherme Lopes da Silva ${ }^{2}$ Marcelo Augusto de Araújo ${ }^{3}$ Bruna de Moraes Martins Games ${ }^{2}$ \\ Jefferson Filgueira Alcindo ${ }^{2}$ Celso Antônio Rodrigues ${ }^{1}$ Paulo Sergio Patto dos Santos ${ }^{2}$
}

${ }^{1}$ Faculdade de Medicina Veterinária e Zootecnia, Universidade Estadual Paulista (UNESP), Botucatu, SP, Brasil. E-mail: mdeschk@hotmail.com. ${ }^{*}$ Corresponding author.

${ }^{2}$ Faculdade de Medicina Veterinária, Universidade Estadual Paulista (UNESP), Araçatuba, SP, Brasil.

${ }^{3}$ Faculdade de Medicina Veterinária e Zootecnia, Universidade Federal de Mato Grosso do Sul (UFMS), Campo Grande, MS, Brasil.

\begin{abstract}
The aim of this study was to evaluate the bispectral index (BIS) effects in calves through continuous infusion of propofol with or without fentanyl. Eight Holstein male calves (ages from six to twelve months old) with an average weight of $123 \pm 18 \mathrm{~kg}$ were used. All animals participated in both groups, always keeping a minimum interval of one week between the anesthetic procedures; the calves were randomly distributed between groups. Anesthesia was induced with an intravenous (IV) dose of propofol of $5 \mathrm{mg} \mathrm{kg}^{-1}$ in control group $\left(G_{p}\right)$ or with propofol (4mg $\left.\mathrm{kg}^{-1}\right)$ associated with IV fentanyl $0.001 \mathrm{mg} \mathrm{kg}^{-1}\left(G_{F}\right)$. All the calves were positioned in right lateral recumbency and were allowed to spontaneously breathe room air. Subsequently, the anesthesia was maintained by continuous infusion of propofol at the rate of $0.6 \mathrm{mg} \mathrm{kg}^{-1} \mathrm{~min}^{-1} \mathrm{IV}$ in $G_{p}$ and associated with the infusion of fentanyl $0.001 \mathrm{mg} \mathrm{kg}^{-1}$ hour ${ }^{-1}$ in $G_{F}$ Measurements of BIS, signal quality index (SQI) and electromyography (EMG) were evaluated before anesthesia induction $\left(T_{B}\right)$, and at 15,30, 45 and 60 minutes after the beginning of continuous drugs infusion $\left(T_{15}, T_{30}, T_{45}\right.$, and $T_{60}$, respectively). The heart rate (HR), respiratory rate (f), end-tidal carbon dioxide tension (ETCO) and recovery times were evaluated as well. No significant differences were observed between the groups in the BIS variables and the recovery time was longer in $G_{F}$ Co-administration of propofol and fentanyl infusions, at the doses reported here, did not change the values of BIS in cattle, but delayed the recovery time.
\end{abstract}

Key words: calves, ruminants, balanced anesthesia, anesthetic monitoring.

Indice biespectral em bezerros submetidos à infusão contínua de propofol associado ao fentanil

RESUMO: O estudo teve por objetivo avaliar o indice biespectral (BIS) durante a infusão contínua de propofol associado ou não ao fentanil em bezerros. Foram utilizados oito animais machos entre seis e doze meses de idade, holandeses, com massa corporal média de $123 \pm 18 \mathrm{~kg}$. Todos os animais participaram de ambos os grupos, respeitando-se sempre um intervalo mínimo de uma semana entre uma anestesia e outra, sendo aleatoriamente distribuidos entre os grupos. A anestesia nos bezerros foi induzida com propofol na dose de $5 \mathrm{mg} \mathrm{kg}^{-1}$; intravenoso (IV), grupo controle $\left(G_{p}\right)$ ou propofol $4 \mathrm{mg} \mathrm{kg}^{-1}$ associado ao fentanil $0,001 \mathrm{mg} \mathrm{kg}^{-1}$; IV, grupo fentanil $\left(G_{F}\right)$ e posicionados em decúbito lateral direito, onde permaneceram respirando espontaneamente ar ambiente. Ato contínuo, a manutenção anestésica foi realizada pela infusão contínua de propofol na taxa de 0,6mg $\mathrm{kg}^{-1} \mathrm{~min}^{-1}$; IV G $G_{p}$ associado ou não à infusão de fentanil $0.001 \mathrm{mg} \mathrm{kg}^{-1} \mathrm{hora}^{-1} G_{F}$ A mensuração das variáveis do $B I S$, índice de qualidade de sinal (IQS) eletromiografia (EMG), frequência cardiaca (FC), frequência respiratória (f) e dióxido de carbono ao final da expiração (ETCO) foram avaliadas antes da indução anestésica no momento basal ( $\left.M_{B}\right)$, e 15, 30, 45 e 60 minutos após o início da infusão contínua dos fármacos $\left(M_{15}, M_{30}, M_{45}\right.$ e $M_{60}$, respectivamente); o tempo de recuperação também foi avaliado. Não foram observadas diferenças significativas entre os grupos nas variáveis do BIS e o tempo de recuperação foi maior no $G_{F}$ A co-administração das infusões de propofol e fentanil, nas doses utilizadas nesse estudo, não alterou os valores do BIS em bezerros, porém, prolongou o tempo de recuperação. Palavras-chave: bezerros, ruminantes, anestesia balanceada, monitoração anestésica.

\section{INTRODUCTION}

The use of different intravenous (IV) anesthetic drugs for induction and maintenance of general anesthesia, also known as total intravenous anesthesia (TIVA), facilitates patient anesthesia and analgesia owing to the depression of the central nervous system (CNS), which causes a loss of awareness and a lack of response to noxious stimuli (MUSK et al., 2005).

Propofol is considered a key alternative among the various drugs that are used in IV anesthesia protocols SELMI et al. (2005), because of its pharmacokinetic characteristics, including rapid 
clearance and high volume of distribution, despite its lack of analgesic properties. Propofol is an effective IV agent for maintaining anesthesia by constant rate infusion (CRI) in several species, including llamas DUKE et al. (1997), horses OKU et al. (2006); UMAR et al. (2015), pigs XIAO et al. (2014), dogs LOPES et al. (2008a), and cattle DESCHK et al. (2015), in addition to its extensive use as an inducing agent.

Similarly, fentanyl, which is a $\mu$-opioid receptor agonist, is used in many species via administration of CRI to provide analgesia during anesthesia with propofol (SMITH et al., 1994). Fentanyl has already been used as an anesthetic and as a pre-anesthetic in buffalos, in combination with different alpha-2 receptor agonists SINGH et al. (2013). However, its use in cattle has only been reported as an adjunctive analgesic, administered as a bolus WILSON et al. (2000), and not as an agent for continuous infusion in these species.

When using these drugs to maintain anaesthesia, the assessment of anaesthetic depth is mandatory. In addition to ocular reflex testing, further methods for assessing CNS depression may also be useful, including electroencephalogram (EEG), which may be effectively correlated with changes in the level of consciousness, and is a continuous and noninvasive measurement. Nonetheless, the routine use of EEG was impractical because of the complexity of its parameters and operator-dependent nature for the interpretation of results DUARTE, (2006); CAMPAGNOL et al. (2007). Since then, the bispectral index (BIS) monitor was developed through extensive research to numerically assess the degree of anesthetic depth of patients.

The interpretation of BIS monitor values is relatively simple, with values ranging from zero to 100 . In humans, zero corresponds to an isoelectric EEG, with the total suppression of cortical electrical activity, and 100 corresponds to a normal state of consciousness (HAJAT et al., 2017). In dogs, values ranging from 40 to 60 represent an adequate anesthetic plan, without occuring intraoperative awareness (GUERRERO \& NUNES, 2003).

Another key issue during an anesthetic procedure is the assessment of patients anesthetic depth. An inadequate anesthetic plane may be harmful for the large-sized animal and surgical team. Its use has been reported in horses (HAGA \& DOLVIK, 2002) and in calves (ARAUJO et al., 2015; DESCHK et al., 2016).

This study aimed to assess the use of BIS monitoring during CRI of propofol alone, or combined with fentanyl in cattle. Moreover, to evaluate its effects over the following variables: heart rate $(\mathrm{HR})$, respiratory rate $(f)$, end-tidal $\mathrm{CO}_{2}$ concentration $\left(\mathrm{ETCO}_{2}\right)$ and recovery times.

\section{MATERIALS AND METHODS}

This prospective, randomized, nonblinded, crossover study. Eight Holstein bull calves, with ages ranging from six to twelve months (mean weight: $123 \pm 18 \mathrm{~kg}$ ) were enrolled in this study. Based on a completed blood count performed two days prior induction of anaesthesia and a physical examination (HR and $f$, rectal temperature and the inspection of the color of the visible mucosae) on the day of the experiment, they were considered healthy and classified as ASA 1 (American Society of Anesthesiologists).

Calves were randomly distributed between the groups, via simple, random sampling. All animals were anesthetized twice and participated in both groups, with at least a one-week interval between each induction of anesthesia.

After selection and weighing, the animals were subjected to water and feed fasting for 24 and 12 hours, respectively. On the day before the experiment, each animal was restrained in a standing position in order to perform trichotomy on the area of the left jugular and cephalic veins and on the frontal, cephalic, and zygomatic areas to place the BIS electrodes. On the day of the experiment, the animal was placed on the surgical table and restrained in a right lateral decubitus position; an introducer ${ }^{\mathrm{a}}$ was placed in the left jugular vein using the Seldinger technique, through which a SwanGanz catheter was introduced for CRI of propofol ${ }^{\mathrm{b}}$, allowing for maintenance fluid therapy with the administration of Ringer's solution with lactate ${ }^{c}$, at an infusion rate of $5 \mathrm{~mL} \mathrm{~kg}^{-1}$ hour $^{-1}$. Another catheter ${ }^{\mathrm{d}}$ (20G) was placed in the left cephalic vein for IV administration of fentanyl.

After preparation and instrumentation, the animal remained restrained in right, lateral decubitus for a 10-minutes period to minimize the effect of animal handling stress on the baseline values of the study variables. Baseline parameters were assessed immediately before anesthetic induction $\left(\mathrm{T}_{\mathrm{B}}\right)$ and included BIS, SQI, EMG, HR, $f$ and $\mathrm{ETCO}_{2}$. Immediately after baseline parameters recording, anesthesia was induced with propofol at an IV dose of $5 \mathrm{mg} \mathrm{kg}^{-1}$, in the group that was anesthetized with propofol infusion only $\left(G_{p}\right)$. In the group $\mathrm{G}_{\mathrm{F}}$, the propofol dose was $4 \mathrm{mg} \mathrm{kg}^{-1}$ mixed with $0.001 \mathrm{mg} \mathrm{kg}^{-1}$ fentanyl, in the same syringe, 
for two minutes, in the group that was anesthetized with propofol infusion combined with fentanyl $\left(\mathrm{G}_{\mathrm{F}}\right)$. Immediately after, the animals were intubated, using a long, blade laryngoscope with tracheal probes of compatible size, while maintaining the cuff inflated throughout the anesthetic procedure.

The calves were hoisted, transferred onto a surgical table, placed in right lateral recumbency and were allowed to breathe room air $\left(\mathrm{FiO}_{2}=0.21\right)$ throughout the experiment Immediately thereafter, anesthesia was maintained with a CRI of propofol, administered using an infusion pump ${ }^{\mathrm{e}}$ at an IV rate of $0.6 \mathrm{mg} \mathrm{kg}^{-1} \mathrm{~min}^{-1}$, combined with or without the CRI of fentanyl at a $0.0 .001 \mathrm{mg} \mathrm{kg}^{-1}$ hour ${ }^{-1}$ infusion rate, for 60 minutes. The use of these infusion rates was described by DESCHK et al. (2015), TRANQUILLI et al. (2007) and pilot studies performed at our institution.

Selected variables were assessed at $T_{B}$ and at 15,30, 45 and 60 minutes after the beginning of the CRI of propofol with or without fentanyl. The assessment of anesthetic recovery began as soon as the drug infusion was completed.

Heart rate was assessed using an electrocardiograph set to read in DII derivation. Respiratory rate was assessed via a direct read of the monitor ${ }^{\mathrm{f}}$ using a suction sensor placed in front of the nostrils on the face mask outlet. This set-up was connected to the end portion of the orotracheal tube. End-tidal carbon dioxide tension values were assessed from a direct read of a capnograph ${ }^{\mathrm{g}}$ using the placement of the suction sensor in a similar manner to its placement during $f$ assessment.

Direct monitoring of BIS was used

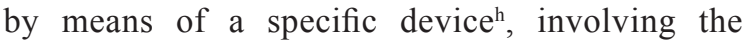
placement of its electrodes ${ }^{i}$ in the frontotemporal position adapted from CAMPAGNOL et al. (2007). Electrode impedance was automatically checked using the monitor, and the electrodes were discarded if the impedance was higher than $7.5 \mathrm{k} \Omega$, as recommended by the manufacturer. The signal quality index (SQI) was also assessed and the BIS discarded when the SQI was lower than 50. Bispectral index values were recorded, and had their mean values calculated, at all time points for one minute. In addition to BIS, the electromyography (EMG) and SQI values were also assessed.

After 60 minutes of anesthesia, the infusions were stopped. Anesthetic recovery involved the observation of the animal in the recovery room of a surgical center with a rubber floor and padded walls. Animal contact was avoided, and the animal was engaged only if it showed intense movements so as to prevent it from hitting its head on the floor. The times between the cessation of the CRI of propofol and the positioning of the animal in sternal recumbency (SR) and the standing position (SP), were recorded.

Data were tested for normality using the Shapiro-Wilk test and subjected to analysis of variance for repeated measures using the MIXED procedure of the Statistical Analysis System (SAS) and multiple mean comparisons with the Least Squares Means (LSMEANS), adjusted for the Tukey's test at a 5\% significance level. Statistical analysis of variables without normal distribution was performed using the Friedman test for comparison between the times points and the Wilcoxon signed-rank test for comparison between groups. Data were analyzed using the software SAS 9.3 (SAS, 2011).

\section{RESULTS}

No additional boluses were required to induce general anaesthesia, in any calve. Endotracheal intubation was successfully and smoothly performed in most of the calves. Only one animal from the group $\mathrm{G}_{\mathrm{F}}$ showed a small quantity of ruminal liquid reflux during intubation, albeit without any repercussions regarding the tracheal aspiration of such contents.

After anaesthetic induction, HR was higher for both groups at all time points compared to baseline, with the exception of GF at T30. Between treatments, differences in HR were only seen at T15. Compared to baseline, f was significantly lower at all time points compared with TB in both treatments, with no differences between them. With regard to $\mathrm{ETCO}_{2}$, the values were significantly lower at baseline compared with all the other time points. No differences between treatments were observed within this parameter.

The BIS and EMG values were significantly lower throughout all the period compared to baseline, with no differences between treatments. No significant differences in sternal recumbency times occurred between groups (Table 1). However, animals receiving in group GF required longer periods of time to adopt the standing position than those in group Gp (Table 2).

\section{DISCUSSION}

It is worth highlighting that the methodology that was used in the present study 
Table 1 - Mean \pm standard deviation of the variables of heart rate $(\mathrm{HR})$, respiratory rate $(f)$ end-tidal $\mathrm{CO}_{2}$ concentration $\left(\mathrm{ETCO}_{2}\right)$, bispectral index (BIS), signal quality index (SQI) and electromyography (EMG) assessed in calves $(n=8)$ anesthetized by continuous infusion of propofol at a rate of $0.6 \mathrm{mg} \mathrm{kg}^{-1} \mathrm{~min}^{-1}$; intravenous (IV), combined with or without fentanyl infusion at $0.001 \mathrm{mg} \mathrm{kg}^{-1}$ hour $^{-1}$.

\begin{tabular}{|c|c|c|c|c|c|c|}
\hline Variable & Treatment & $\mathrm{T}_{\mathrm{B}}$ & $\mathrm{T}_{15}$ & $\mathrm{~T}_{30}$ & $\mathrm{~T}_{45}$ & $\mathrm{~T}_{60}$ \\
\hline \multirow{2}{*}{ HR (beats minute ${ }^{1}$ ) } & $\mathrm{G}_{\mathrm{P}}$ & $74 \pm 24^{\mathrm{a}^{*}}$ & $104 \pm 20^{\mathrm{b}^{*}}$ & $98 \pm 15^{\mathrm{a}^{*}}$ & $106 \pm 12^{\mathrm{a}^{*}}$ & $110 \pm 10^{\mathrm{a}^{*}}$ \\
\hline & $\mathrm{G}_{\mathrm{F}}$ & $72 \pm 13^{\mathrm{a}^{*}}$ & $122 \pm 33^{\mathrm{a}^{*}}$ & $113 \pm 28^{\mathrm{a}^{*}}$ & $112 \pm 23^{\mathrm{a}^{*}}$ & $116 \pm 23^{a^{*}}$ \\
\hline \multirow{2}{*}{$f_{R}$ (breaths minute ${ }^{1}$ ) } & $\mathrm{G}_{\mathrm{P}}$ & $42 \pm 12^{\mathrm{a}^{*}}$ & $17 \pm 2^{\mathrm{a}^{*}}$ & $18 \pm 3^{\mathrm{a}^{*}}$ & $19 \pm 2^{\mathrm{a}^{*}}$ & $20 \pm 3^{\mathrm{a}^{*}}$ \\
\hline & $\mathrm{G}_{\mathrm{F}}$ & $38 \pm 18^{\mathrm{a}^{*}}$ & $20 \pm 6^{\mathrm{a}^{*}}$ & $18 \pm 1^{\mathrm{a}^{*}}$ & $18 \pm 1^{\mathrm{a}^{*}}$ & $18 \pm 1^{\mathrm{a}^{*}}$ \\
\hline \multirow{2}{*}{$\mathrm{ETCO}_{2}(\mathrm{mmHg})$} & $\mathrm{G}_{\mathrm{P}}$ & $17 \pm 5^{\mathrm{a}^{*}}$ & $54 \pm 4^{\mathrm{a}^{*}}$ & $56 \pm 4^{\mathrm{a}^{*}}$ & $55 \pm 5^{\mathrm{a}^{*}}$ & $54 \pm 5^{\mathrm{a}^{*}}$ \\
\hline & $\mathrm{G}_{\mathrm{F}}$ & $19 \pm 7^{\mathrm{a}^{*}}$ & $55 \pm 4^{\mathrm{a}^{*}}$ & $55 \pm 5^{\mathrm{a}^{*}}$ & $56 \pm 6^{\mathrm{a}^{*}}$ & $53 \pm 8^{\mathrm{a}^{*}}$ \\
\hline \multirow{2}{*}{ BIS } & $\mathrm{G}_{\mathrm{P}}$ & $93 \pm 5^{\mathrm{a}^{*}}$ & $52 \pm 10^{\mathrm{a}^{*}}$ & $51 \pm 8^{\mathrm{a}^{*}}$ & $51 \pm 8^{\mathrm{a}^{*}}$ & $51 \pm 8^{\mathrm{a}^{*}}$ \\
\hline & $\mathrm{G}_{\mathrm{F}}$ & $89 \pm 9^{\mathrm{a}^{*}}$ & $56 \pm 11^{\mathrm{a}^{*}}$ & $53 \pm 8^{\mathrm{a}^{*}}$ & $52 \pm 11^{\mathrm{a}^{*}}$ & $54 \pm 12^{\mathrm{a}^{*}}$ \\
\hline \multirow{2}{*}{ SQI (\%) } & $\mathrm{G}_{\mathrm{P}}$ & $87 \pm 8^{\mathrm{a}^{*}}$ & $97 \pm 3^{\mathrm{a}^{*}}$ & $93 \pm 6^{\mathrm{a}^{*}}$ & $90 \pm 15^{\mathrm{a}^{*}}$ & $96 \pm 4^{\mathrm{a}^{*}}$ \\
\hline & $\mathrm{G}_{\mathrm{F}}$ & $86 \pm 12^{\mathrm{a}^{*}}$ & $89 \pm 14^{\mathrm{a}^{*}}$ & $89 \pm 11^{\mathrm{a}^{*}}$ & $93 \pm 9^{a^{*}}$ & $91 \pm 14^{\mathrm{a}^{*}}$ \\
\hline \multirow{2}{*}{ EMG } & $\mathrm{G}_{\mathrm{P}}$ & $51 \pm 3^{a^{*}}$ & $35 \pm 4^{\mathrm{a}^{*}}$ & $33 \pm 4^{\mathrm{a}^{*}}$ & $35 \pm 4^{\mathrm{a}^{*}}$ & $32 \pm 5^{\mathrm{a}^{*}}$ \\
\hline & $\mathrm{G}_{\mathrm{F}}$ & $51 \pm 4^{\mathrm{a}^{*}}$ & $33 \pm 5^{\mathrm{a}^{*}}$ & $34 \pm 6^{\mathrm{a}^{*}}$ & $33 \pm 2^{\mathrm{a}^{*}}$ & $32 \pm 5^{\mathrm{a}^{*}}$ \\
\hline
\end{tabular}

Different superscript letters for values within a treatment are significantly different $(\mathrm{P}<0.05) .{ }^{*} \mathrm{GF}$ significantly different from GP at the same time point $(\mathrm{P}<0.05)$.

was performed adequately and smoothly. To our knowledge, this is the first report of the administration of a CRI of propofol combined with fentanyl in calves, based on the literature review performed. The propofol dose which was used was retrieved from DESCHK et al. (2015), who assessed two different propofol infusion rates in calves $\left(0.6 \mathrm{mg} \mathrm{kg}^{-1} \mathrm{~min}^{-1}\right.$ and $\left.0.8 \mathrm{mg} \mathrm{kg}^{-1} \mathrm{~min}^{-1}\right)$, whereby the best results were assessed using the $0.6 \mathrm{mg} \mathrm{kg}^{-1} \mathrm{~min}^{-1}$ infusion rate in this study.

The necessity of adding an analgesic to this protocol as an adjunct method for TIVA was identified in the present study. Thus, the drug chosen was fentanyl, using an infusion rate of $0.001 \mathrm{mg} \mathrm{kg}^{-1}$ hour $^{-1}$ as indicated by TRANQUILLI et al. (2007).

After beginning the infusion, the HR increased significantly in both groups, remaining

Table 2 - Mean \pm standard deviation of the sternal recumbency (SR) time, in minutes, and the standing position (SP) time, in minutes, according to groups.

\begin{tabular}{lcc}
\hline Variable & \multicolumn{2}{c}{ SP e SR $\left(\overline{\mathbf{X}}_{ \pm s}\right)$} \\
\cline { 2 - 3 } & $\mathrm{G}_{\mathrm{P}}$ & $\mathrm{G}_{\mathrm{F}}$ \\
Sternal Recumbency & $26 \pm 6 \mathrm{~A}$ & $31 \pm 18 \mathrm{~A}$ \\
Standing Position & $35 \pm 8 \mathrm{~B}$ & $46 \pm 17 \mathrm{~A}$ \\
\hline
\end{tabular}

Means followed by the same letter, in rows, are not different from each other according to the Tukey's test $(\mathrm{P}>0.05)$. high throughout the infusion period, which was in contrast to the findings by DZIKITI et al. (2010), who observed no increase in HR when using propofol and fentanyl or midazolam infusion in goats. A possibility accounting for such a difference might be related to the higher infusion rate $\left(12 \mathrm{mg} \mathrm{kg}^{-1}\right.$ hour ${ }^{-1}$ and $0.02 \mathrm{mg} \mathrm{kg}^{-1}$ hour $\left.{ }^{-1}\right)$ of drugs (propofol and fentanyl, respectively) used in the aforementioned study, which mediated a decrease in HR during the infusion, albeit without statistically, significant differences.

At $\mathrm{T}_{\mathrm{B}}$, the values of $f$ and $\mathrm{ETCO}_{2}$ were the highest and the lowest, respectively, significantly differing from the other time points. These results can be explained by the fact that all animals were restrained at baseline. DZIKITI et al. (2010) also observed significant differences between $T_{B}$ and the other time points, which were assessed when infusing propofol combined with fentanyl in goats. However, that difference was much steeper, with $f$ values of approximately 7 respiratory movements per minute, without requiring the use of mechanical ventilation. An adverse effect of fentanyl is respiratory depression, according to TRANQUILLI et al. (2007). However, the results from our study were similar across both groups $\mathrm{G}_{\mathrm{P}}$ and $\mathrm{G}_{\mathrm{F}}$; thereby, suggesting that the infusion rate that was used was insufficient to cause the expected, adverse effects.

With regard to $\mathrm{ETCO}_{2}$, both groups showed a considerable increase in their values, confirming that the respiratory changes that were 
observed were propofol-mediated and were not attributable to the synergistic effects of fentanyl infusion. Such a significant increase in $\mathrm{ETCO}_{2}$ may also be associated with the position of the animals because of the abdominal compression of the diaphragma, compromising a correct ventilation by reducing the residual lung capacity, even when remaining in lateral decubitus throughout the experimental period.

Bispectral index is still seldom used in cattle anesthesia, mainly due to the cost benefit of the device and the fact that few studies have been conducted in cattle. This has precluded the validation of BIS values because the development of this index for humans, as well as for use in animals, especially in cattle, has only recently begun. Using the BIS, APREA et al. (2014) clearly showed in a case report of the cardiopulmonary resuscitation of a propofol-anesthetized calf that the BIS values that were assessed had varied with cardiovascular function and that BIS was indicative of cerebral perfusion in cattle.

ARAÚJO et al. (2014) and ARAÚJO et al. (2015) reported mean BIS values of approximately 40 when conducting studies in calves using inhalation anesthesia with isoflurane combined with butorphanol infusion, and assessing BIS in isoflurane-anesthetized calves with or without CRI of lidocaine, respectively. Such values were slightly lower than those reported in this study, which is most likely related to the protocol that was used and to the difference in anesthetic plan. Similarly, DESCHK et al. (2015) reported mean BIS values of 50 in calves anesthetized with propofol at two infusion rates and reported no significant differences in the variable between groups, which showed that the increase in infusion rate was insufficient to change BIS values proportionally. This demonstrated that the results from the BIS assessment was directly dependent upon the anesthetic protocol which was used for cattle. Conversely, the study by DESCHK et al. (2015), who also used the same protocol and assessed values that were very similar to those of the present study, suggested that the low infusion rate of fentanyl was insufficient to further depress the CNS of the animals. This resulted in a decrease in the BIS values, and/or a BIS value of approximately 50 in calves anesthetized with CI of propofol.

Considering the method that was used, the BIS values reported herein are presumably reliable because the SQI, which is the parameter assessing signal intensity and quality, did not differ between the time points or the groups. Similarly, EMG did not differ between groups either and had only differed at the baseline values when compared against the other time points in both groups. Additionally, as muscle contraction directly affects the EMG values, the difference between the baseline values and that of the other time points can be explained by the fact that the calves were resisting restraint, and that the subsequent muscle activity would have accounted for the changes in those values. Conversely, the values reported during the infusion period corroborated with those of: GUERRERO \& NUNES, (2003), who used SQI values higher than 90 and EMG values lower than 30; LOPES et al. (2008a), who assessed EMG values lower than 43 and SQI values higher than 92; and LOPES et al. (2008b), who assessed mean SQI values higher than 84 and EMG values lower than 40; thereby, confirming that the difference in the baseline values was directly related to muscle contraction.

The $\mathrm{G}_{\mathrm{F}}$ prolonged recovery times when the animal was positioned in both sternal recumbency and in a standing position, revealing significant differences between the groups only during the SP time. These results go against the findings reported by DZIKITI et al. (2010), who observed no significant differences in the recovery time when combining propofol infusion with the adjunctive administration of midazolam or fentanyl in goats. Those authors also reported that goats from the fentanyl group showed signs of disparate behavior at the time of recovery, displaying unrest, which was also observed in the present study in the animals in group $\mathrm{G}_{\mathrm{F}}$. However, the severity of these effects were less intense and were restricted to chewing movements. Nonetheless, we believed that the incidence of adverse effects during recovery could be similar to those observed by DZIKITI et al. (2010) in goats if the infusion rate of fentanyl was increased.

However, our study is not free of limitations. Another way to assess anesthetic depth involves subjective evaluation, which was not performed in this study, such as the use of Guedel's classification combined with BIS values. Therefore, further studies aims to perform a subjective evaluation of anesthetic depth correlated with BIS values, which should be conducted, in order to define a more reliable range of BIS values for cattle. Moreover, the absence of a painful stimulus to test analgesia against the BIS values could be considered as a limitation, primarily in group $\mathrm{G}_{\mathrm{F}}$. Nonetheless, for ethical reasons, the animals in group $G_{P}$ could not receive a noxious stimulus because no analgesia 
is provided by propofol. Thus, further studies should be performed using other fentanyl infusion rates until the adequate dose that provides anesthesia and analgesia to patients is determined.

\section{CONCLUSION}

In conclusion, propofol infusion combined with or without fentanyl, induced significant respiratory depression without changing the BIS values and prolonged the total recovery time of the group anesthetized with the CRI of fentanyl.

\section{VERBAL REPORT}

${ }^{a}$ Introducer Percutaneous Intro-Flex.5F - Edwards Lifesciences São Paulo, SP.

${ }^{b}$ Propovan 10mg / ml Laboratory Cristália - Pharmaceutical Chemicals Ltda, Itapira, SP.

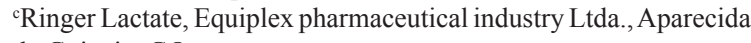
de Goiania, GO.

${ }^{\mathrm{d}}$ Catheter BD Intracath 16G - Becton, Dickinson Ind Surgical. Ltda. - Juiz de Fora, MG.

'Linear Volumetric Infusion Pump ST1000-Samtronic-São Paulo, SP. (Proc. FAPESP $2010 /$ 19568-9)

fDixtal - mod. DX-2020, Manaus, AM. (Proc. FAPESP 2009/08879-6) 'Dixtal, mod. DX-2020 - Module gas analyzer. Manaus, AM. (Proc. FAPESP 2009 / 08879-6)

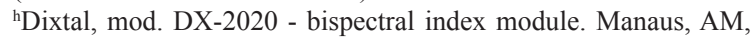
Brazil. (Proc. FAPESP 2009 / 08879-6)

Bis Four Sensor, Aspect Medical Systems, Norwood, MA, USA.

\section{ACKNOWLEDGEMENTS}

The authors wish to thank the Fundacão de Amparo a Pesquisa do Estado de São Paulo (FAPESP) for a scholarship (process no. 2013/09469-1).

\section{BIOETHICS AND BIOSSECURITY COMMITTEE APPROVAL}

The study was approved by Ethics Committee on Animal Use (CEUA; Process FOA-0107-2013).

\section{REFERENCES}

APREA, F. et al. Bispectral index analysis during cardiac arrestand cardiopulmonary resuscitation in a propofol-anesthetized calf. Journal of Veterinary Emergency and Critical Care, v.24, n.2, p. 221-225, 2014. Available from: <http://onlinelibrary.wiley.com/doi/10.1111/ vec.12123/full>. Accessed: Mar. 20, 2015. doi: 10.1111/vec.12123.

ARAÚJO, M.A. et al. Effects of continuous rate infusion of butorphanol in isoflurane-anesthetized calves. Acta Cirúrgica Brasileira, v.29, n.7, p.465-471, 2014. Available from: <http:// www.scielo.br/pdf/acb/v29n7/0102-8650-acb-29-07-00465.pdf>. Accessed: May. 15, 2015. doi: 10.1590/S0102-86502014000700009.

ARAÚJO, M.A. et al. Bispectral index in calves anesthetized with xylazine, midazolam, ketamine, isoflurane and subjected to continuous rate infusion of lidocaine. Acta Cirúrgica Brasileira, v.30, n.1, p.67-72, 2015. Available from: <http://www.scielo.br/pdf/acb/v30n1/0102-8650-acb-30-01-00067. pdf $>$. Accessed: Mar. 25, 2015. doi: 10.1590/S0102-86502015001000009.

CAMPAGNOL, D. et al. Use of bispectral index to monitor depth of anesthesia in isoflurane-anesthetizes dogs. American Journal of Veterinary Research, v.68, n.12, p.1300-1307, 2007. Available from: $<$ http://avmajournals.avma.org/doi/full/10.2460/ajvr.68.12.1300>. Accessed: Aug. 28, 2015. doi: 10.2460/ajvr.68.12.1300.

DESCHK, M. et al. Continuous infusion of propofol in calves: bispectral index and hemodynamic effects. Veterinary Anaesthesia and Analgesia, v.43 p.309-315, 2015. Available from: <http:// onlinelibrary.wiley.com/doi/10.1111/vaa.12302/full>. Accessed: Oct. 25, 2015. doi: $10.1111 /$ vaa.12302.

DZIKITI, B.T. et al. Total intravenous anaesthesia (TIVA) with propofolfentanyland propofol-midazolam combinations in spontaneouslybreathing goats. Veterinary Anaesthesia and Analgesia, v.37, n.6, p.519-525, 2010. Available from: <http://onlinelibrary.wiley.com/ doi/10.1111/j.1467-2995.2010.00568.x/full>. Accessed: Oct. 25, 2014. doi: 10.1111/j.1467-2995.2010.00568.x.

DUARTE L. T.D. Índice bispectral-BIS. In: CAVALCANTI, I.L. et al. Medicina Perioperatória. Rio de Janeiro: Sociedade de Anestesiologia do Rio de Janeiro, 2006. p.209-232.

DUKE, T. et al. Cardiopulmonary effects of propofol infusion in llamas. Veterinary Anaesthesia and Analgesia, v.58, n.2, p.153-156, 1997.

GUERRERO, P.N.H.; NUNES, N. Monitoramento do índice bispectral em cães. Semina: Ciências Agrárias, v.24, n.1, p.163170, 2003. Available from: <http://www.uel.br/revistas/uel/index.php/ semagrarias/article/view/2144/1839>. Accessed: Jun. 10, 2014. doi: 10.5433/1679-0359.2003v24n1p163.

HAGA, H.A.; DOLVIK, N.I. Evaluation of the bispectral index as an indicator of degree of central nervous system depression in isofluraneanesthetized horses. American Journal of Veterinary Research, v.63, n.3, p.438-442, 2002. Available from: <http://avmajournals.avma.org/ doi/pdf/10.2460/ajvr.2002.63.438>. Accessed: Jul. 200, 2014. doi: 10.2460/ajvr.2002.63.438.

HAJAT, Z. et al. The role and limitations of EEG-based depth of anaesthesia monitoring in theatres and intensive care. Anaesthesia, v.72, Suppl.1, p.3847, 2017. Available from: <http://onlinelibrary.wiley.com/doi/10.1111/ anae.13739/full >. Accessed: Apr. 10, 2017. doi: 10.1111/anae.13739.

LOPES, P.C.F. et al. Bispectral index in dogs at three intravenous infusion rates of propofol. Veterinary Anaesthesia and Analgesia, v.35, n.3, p.228-231, 2008a. Available from: <http://onlinelibrary.wiley. com/doi/10.1111/j.1467-2995.2007.00377.x/full>. Accessed: Mar. 20, 2015. doi: 10.1111/j.1467-2995.2007.00377.x.

LOPES, P.C.F. et al. Effects of several inspired oxygen fractions on the bispectral index in dogs submitted tocontinuous infusion of propofol. Arquivo Brasileiro de Medicina Veterinária e Zootecnia, v.58, n.42, p.359-366, 2008b. Available from: <http://www.scielo.br/scielo. php?script=sci_arttext\&pid=S0102-09352008000200014 $>$. Accessed: Sep. 20, 2015. doi: 10.1590/S0102-09352008000200014.

MUSK, G.C. et al. Target-controlled infusion of propofol in dogs evaluation of four targets for induction of anaesthesia. Veterinary Record, v.157, n.24, p.766-770, 2005. Available from: $<$ http://veterinaryrecord. bmj.com/content/157/24/766>. Accessed: Jan. 27, 2015. doi: 10.1136/ vr.157.24.766. 
OKU, K. et al. Cardiovascular effects of continuos propofol infusion in horses. Journal of Veterinary Medical Science, v.68, n.8, p.773-778, 2006. Available from: <https://www.jstage.jst. go.jp/article/jvms/68/8/68_8_773/_pdf>. Accessed: Jan. 27, 2015.

SELMI, A.L. et al. Infusão contínua de propofol em gatos prémedicados com cetamina midazolam. Arquivo Brasileiro de Medicina Veterinária e Zootecnia, v.57, n.3, p.295-299, 2005. Available from: <http://www.scielo.br/scielo.php?script=sci artt ext\&pid=S0102-09352005000300003>. Accessed: Jan. 30, 2015. doi: 10.1590/S0102-09352005000300003.

SINGH, G.D. et al. Clinicophysiological and haemodynamic effects of fentanyl with xylazine, medetomidine and dexmedetomidine in isoflurane-anaesthetised water buffaloes (Bubalusbubalis). Journal of the South African Veterinary Association, v.84, n.1, p.1-11, 2013. Available from: < http://www.jsava.co.za/index.php/ jsava/article/view/67>. Accessed: Dec. 10, 2015. doi: 10.4102/ jsava.v84i1.67.

SMITH, I. et al. Propofol: anupdate on its clinical use. Anesthesiology, v.81, n.4, p.1005-1043, 1994. Available from: $<$ http://anesthesiology. pubs.asahq.org/article.aspx?articleid $=1949254>$. Accessed: Dec. 10,2015
TRANQUILLI, W.J. et al. Ruminants. In: Lumb \& Jones' veterinary anesthesia and analgesia. 4.ed. Iowa: Blackwell: Thomas w. Riebold, 2007. p.731-746.

UMAR, M.A. et al. Cardiovascular effects of total intravenous anesthesia using ketamine-medetomidine-propofol (KMP-TIVA) in horses undergoing surgery. Journal of Veterinary Medical Science, v.77, n.3, p.281-288, 2015. Available from: <https:// www.jstage.jst.go.jp/article/jvms/77/3/77_14-0370/ article> Accessed: Jan. 10, 2016. doi: 10.1292/jvms. $\overline{14}-0370$.

WILSON, D.V. et al. Perioperative management of calves undergoing implantation of a left ventricular assist device. Veterinary Surgery, v.29, n.1, p.106-118, 2000. Available from: $\quad<$ http://onlinelibrary.wiley.com/doi/10.1111/j.1532 950X.2000.00106.x/full>. Accessed: Mar. 08, 2015. doi: 10.1111/j.1532-950X.2000.00106.x.

XIAO, Y. et al. Different effects of propofol and isoflurane on cochlear blood flow and hearing function in Guinea pigs. PLoS One, v.9, n.5, p.1-7, 2014. Available from: <http:// journals.plos.org/plosone/article?id=10.1371/journal. pone.0096861>. Accessed: Nov. 27, 2015. doi: 10.1371/ journal.pone.0096861. 